\title{
Traces of Ideology and Fictional Scenarios in Translating the Qurān: A Critical Discourse Analysis of Nine Cases across Twenty Versions in English
}

\author{
Abdunasir I. A. Sideeg ${ }^{1}$ \\ ( $\mathrm{PhD}$ in Critical Applied Linguistics) \\ Lecturer of Linguistics at Yanbu University College, (KSA) \\ Dept. of Applied Linguistics
}

\begin{abstract}
This research article aims to explore and critically examine nine cases in which traces of ideology are explicitly or implicitly involved in creating 'fictional scenarios' in the context of translating the Qurān into English. The goal is to trace the ideological agendas that underpin these 'fictional scenarios' and the way they shape the Qurānic message. The article employs a critical qualitative framework that allows for the researcher's subjective interpretations of the relevant texts. Critical Discourse Analysis (CDA) is used for the analysis of data as this approach provides convenient modes of critical thinking to carry out the present thesis. In this article, nine cases across twenty versions of the Qurān in English are investigated. Major findings indicate that traces of ideology are the genesis of fictional scenarios that drastically alter the Qurānic message. Neo-Mutazilite, modernist, and Qurānist traces of ideology significantly contribute to produce alien readings of some Qurānic texts as in cases (1) to (6). Sufi and gnostic ideologies are crucial in creating a fictional scenario in which the Prophet Muhammad is supposed to have attained the Beatific Vision in the Night of Ascension:[cases (7)].Plus, the desire to create 'exotic worlds' and intrude into the privacy of women has its own legacy in the world of ideology and significantly contributes to create 'fictional scenarios' in translating particular Qurānic verses:[case (8)]. Nonetheless, sometimes complex traces of ideology may combine together to create an ideologicallymotivated fictional reading: [case (9)].
\end{abstract}

Keywords: Qurān, fictional scenarios, traces of ideology, critical discourse analysis (CDA), Sufi

\section{INTRODUCTION}

Recent research in translation studies focuses on the significant role of ideology in translation and the strong affinity between the construct of ideology and the process and product of translation. In the words of Aichele (2002), "no translation is ever complete. The selection of possible meanings to be excluded or included is always ideological". Lefevere's (2004) maintains that "on every level of the translation process, it can be shown that, if linguistic considerations enter into conflict with considerations of an ideological and/or poetological nature, the latter tend to win out" (p. 39). In the context of translating the Qurān, the affinity between ideology and translation is highly significant as the Qurān itself is essentially an ideological text in which both simple transparency and conceptual density remarkably merge and resolve. Virtually, translating religious texts is a purely ideological act. Rarely would a translator embark on the serious and time-consuming effort of translating the Qurān without having some sort of ideological motivation(s).

Ideology, in Hatim and Mason's (1997) designation, is “a body of assumptions which reflects the beliefs and interests of an individual, a group of individuals, a social institution, etc., and which ultimately finds expression in language" (p. 218). Van Dijk (2006) maintains that "whatever elle ideologies are, they are primarily some kind of 'ideas', that is, belief systems" (2006, p. 116). In the context of this article, ideology refers to the "totality of the translator's weltanschauung, political agenda, and sectarian or religious views without the value judgment of positive or negative that usually accompanies the term" (Sideeg, 2015, p.215). The designation 'traces of ideology' is employed here as "ideological perspectives are often hidden or opaque, to be rediscovered and read through the lens of a meticulous, critical, and in-depth analysis of relevant texts and discourse" (Sideeg, 2015, p.215).

The first rigorous translation of the Qurān in English was made by Ross in 1649. Though of little value or significance today, Ross' version, which is based on the French translation of Sieur du Ryer's (1647) L'Alcoran de

${ }^{1}$ Corresponding Author: sidiga@rcyci.edu.sa 
Mahomet, reveals how the translator's ideology significantly affects both the process and product of translation. The title page of Ross' translation reads as follows:

The Alcoran of Mahomet, Translated out of Arabick into French. By the Sieur du Ryer, Lord of Malezair, and Resident for the French King, at ALEXANDRIA. And Newly Englished, for the satisfaction of all that desire to look into the Turkish Vanities.

In the preface to the translation Ross (1647) further adds:

Thou shalt finde it of so rude, and incongruous a composure so farced with contradictions, blasphemies, obscene speeches, and ridiculous fables, that some modest, and more rationall Mahometans have thus excused it ... Such as it is, I present to thee, having taken the pains only to translate it out of French, not doubting, though it hath been a poyson, that hath infected a very great, but most unsound part of the universe, it may prove an Antidote, to confirm in thee the health of Christianity (A2, A3).

Asad (1980), the second European Muslim to translate the Qurān, observes that "among the existing translations in almost all of the major European languages there is many a one that has been inspired by malicious prejudice and especially in earlier times - by misguided 'missionary' zeal..." (p. 3). Kidwai (1987), a significant figure in the field of Qurān translation studies, acknowledges the primacy of ideological concerns in the act of translating the Qurān. For him, it is the ideological encounter between the Muslim world and Western powers that has initiated the whole process of Qurān translation in modern times. The need to have the Qurān translated to English by a Muslim "arose mainly out of the desire to combat" orientalist efforts that usually produce "erroneous and confounding" versions in the European languages. "The same rationale", Kidwai (1987) states, "applies to sectarian movements within Islam or even to renegade groups outside the fold of Islam.... Their considerable translational activities are motivated by the urge to proclaim their ideological uniqueness". In the same line, Rafiabadi (2003) rightly observes that an interesting fact about the Qurān is that scholars from various sects and faiths contest within the domain of translating the Qurān into English. He quotes Griefenhagen's (1992:284) statement that "by the 20th century, the translation of the Qurān into English became the locus of power struggles, not only between Islam and West, but also between orthodox groups within Islam and heterodox offshoots (p. 215).

Griefenhagen's statement on "power struggles" between "orthodox groups within Islam and heterodox offshoots" is highly significant. In the literature on Qurān translation, it is customary to come across agitated statements that discredit translations made by outsiders (orientalists) on the alleged 'ideological biases' in these translations. Yet, scrutiny and critical analyses show that translations made by insiders (translators working within the Islamic community and culture) are more problematic and considerably much biased as the quality and quantity of distortion and sectarian readings in the majority of the insider translations is much weighty and significantly manifest than in most of the translations made by outsiders (Sideeg, 2014). It is high time that researchers in the field critically addressed relevant issues of Qurān translations without biased misconceptions on the status of some Qurān translations. A significant effort in this trend is Al-Shabab's (2001), (2008) insightful analysis of Marracci's Latin translation 'Refutato Alcorani'. Even though this translation seems to be culturally and ideologically biased as its title suggests, Al-Shabab acknowledges and uncovers Marracci's "strong commitment to "exactitude", 'methodological achievement', and "everlasting contribution".

\subsection{What is a Fictional Scenario in Translating the Qurān?}

Fictional scenarios are abundant in almost all the classical exegetes of the Qurān. A proverbial example of these fictional scenarios is what Ibn Kathir (one of the most popular classical exegeses among Muslims today) narrates on the interpretation of this verse:

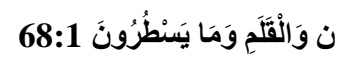

Control Version. $\quad$ Nun. By the pen and what they write.

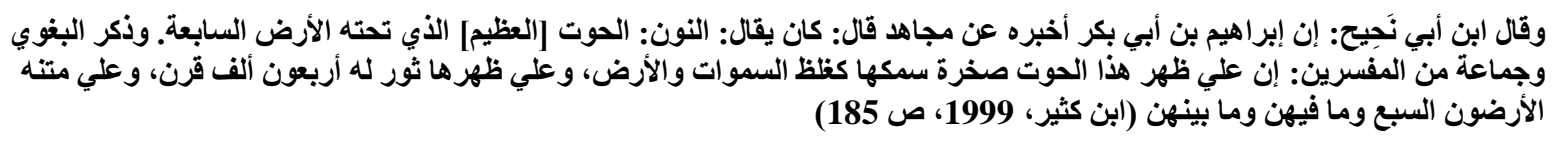

Abu Naheeh said that Ibrahim Ibn AbuBaker narrated from Mujahid that it was said: The 'Nun' is the great fish under which lies the seventh earth. Al-Baghwai, among a group of other exegetists, narrated that on the back of this fish there is a rock as thick as the earth and heavens, and on this rock there is an ox with forty thousand horns. On the back of that ox there lie the seven earths and all that on them and between them. 
The designation 'fictional scenario' in translating the Qurān is used in this article to describe cases in which the translator changes the facts of the SL text or adds to them what produces a piece of fiction rather than a TL text acceptable within the boundaries and variations in doing translation. This applies when the product of translation is in stark opposition to the linguistic and contextual meanings of the SL text and to the huge bulk of translations made by people of different backgrounds at different times. Though the act of translation may often involve some sort of addition or reinterpretation, from an ideological perspective there is always a clear line between 'fictional scenarios' and tolerable expansions or interpretations motivated by the process of translation. Translation, as Tymoczko and Gentzler (2002) maintain, is not merely an accurate replica of a text. It is rather a "deliberate and conscious act of selection, assemblage, structuration, and fabrication - and even, in some cases, of falsification, refusal of information, counterfeiting, and the creation of secret codes" (p. xxi). Fictional scenarios in translating the Qurān are mainly produced by these instances of "falsification, refusal of information, counterfeiting, and the creation of secret codes."

In the $20^{\text {th }}$ century, the Muslim world witnessed a series of modernist thinkers such as Taha Hussayn, Amin AlKhuli, and Muhammad Ahmed Khalafallah who treated the Qurān as a literary text that uses fictional scenarios in which historical authenticity is irrelevant. Khalafallah, for instance, "emphasized that the stories of the Qurān are allegories, amthal, not intended to convey historical fact. As amthal they belong to the category of mutashabihat or the ambiguous" (Abu Zayd, 2006, p.47). In fact, it is in Khalafallah's (1947) thesis on the art of story-telling in the Qurān these approaches that interpret the Qurān as a work of fiction find their mature and strongest articulation. Khalafallah claims that the Qurān contains the three basic genres of fiction: historical stories, allegories, and mythologies. Yet, even in the case of the first genre, Khalafallah maintains that it is not required that their material or events be identical with factual truths:

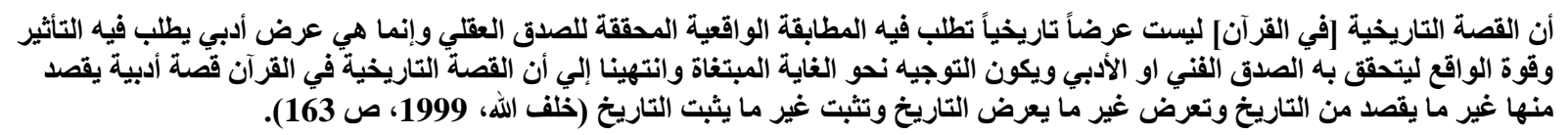

The historical story in the Qurān is not a historical narrative that is required to be realistically identical to the facts of intellectual truth. It is rather a literary narrative that is required to be effective and realistic enough to attain artistic or literary truth and achieve the intended goal. We conclude that the historical story in the Qurān is a literary narrative intended for purposes others than those of history, depicts events others than those depicted in history, and validates things others than those validated in history.

In almost all his arguments on the fictional status of the Qurānic stories, Khalafallah relies heavily on A-Zamakhshri (an early Mutazilite scholar, died 1143), Al-Razi (an early Asharite and rationalist thinker, died 1209), and Muhammad Abduh (died 1905) and Rashid Ridha (died 1935) (two of the neo-Mutazilite and modernist reformers). Khalafallah is very clear on his stance on the mythological nature of the Qurānic stories; he openly declares that:

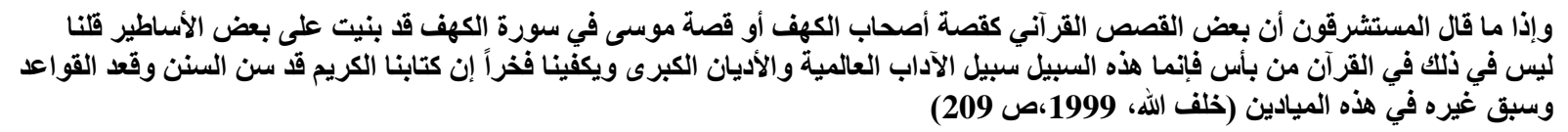

When the orient lists claim that some of the Qurānic narratives, such as the story of the people of the cave and the story of Moses in Surat Al-Kahf (the Cave), are based on mythologies, we would say that there is nothing wrong about this in the Qurān. This is the way world literary masterpieces and great religions work. We are proud enough that our Holy Book has been the first to pave the way and lay down the principles in these fields.

Khalafallah's theory overtly outlines a philosophical paradigm for treating the Qurān as a work of fiction and later as a 'human text' (Abu Zyd, 2006). Nonetheless, the approach adopted by Hussayn, Al-Khuli, and Khalfallah among others is marred bya grave methodological weakness which seriously threatens its validity and deems it null and void. Khalfallah's whole thesis suffers from the fallacy of the undistributed middle. This is a logical fallacy that occurs when a syllogism's middle term is undistributed in both of the premises. Below is an illustration of this fallacy:

Major Premise: All $\boldsymbol{p}$ are $\boldsymbol{m}$.

Minor Premise: All $\boldsymbol{q}$ are $\boldsymbol{m}$.

Conclusion: $\quad$ Therefore, all $\boldsymbol{p}$ are $\boldsymbol{q}$.

This could concretely be shown as thus: 


\section{Major Premise:}

Minor Premise:

Conclusion:
Computers have screens.

TVs have screens.

Therefore, TVs are computers.

The source of invalidity here is that we are using the class 'things with keyboards' to relate TVs to computers, but we never mention 'all things with keyboards'. That is, the term 'things with keyboards' is not distributed in either one (or both) of the premises. In other words, the middle term in the premises never refers to all of the members of the category it describes. This is exactly the way Khalafallah's thesis works:

Major Premise:

Minor Premise:

Conclusion:
The Qurān uses literary devices and techniques.

Fiction uses literary devices and techniques.

Therefore, the Qurān is fiction.

In this syllogism, the fallacy stems from the disastrous confusion of the terms literature and fiction. If the Qurān could be seen as a literary genre or a form of 'literature', it does not follow that it is a work of fiction. In an incisive analysis on the question of what literature is, Eagleton (2003) succinctly argues that literature is definable not according to whether it is fictional or 'imaginative', but because it uses language in peculiar ways. On this theory, literature is a kind of writing which, in the words of the Russian critic Roman Jakobson, represents an 'organized violence committed on ordinary speech'. Literature transforms and intensifies ordinary language, deviates systematically from everyday speech. If you approach me at a bus stop and murmur 'Thou still unravished bride of quietness,' then I am instantly aware that I am in the presence of the literary. I know this because the texture, rhythm and resonance of your words are in excess of their abstract able meaning - or, as the linguists might more technically put it, there is a disproportion between the signifiers and the signifieds. Your language draws attention to itself, flaunts its material being, as statements like 'Don't you know the drivers are on strike?' do not (p.2).

I have reproduced Eagleton's long but significant quotation because it accurately and precisely explains the distinctions between literature and fiction. For almost two decades, I have been using the essence of Eagleton's designation as visualized in the diagram below to show freshman students of English language and literature the interactions and distinctions between the basic literary genres:

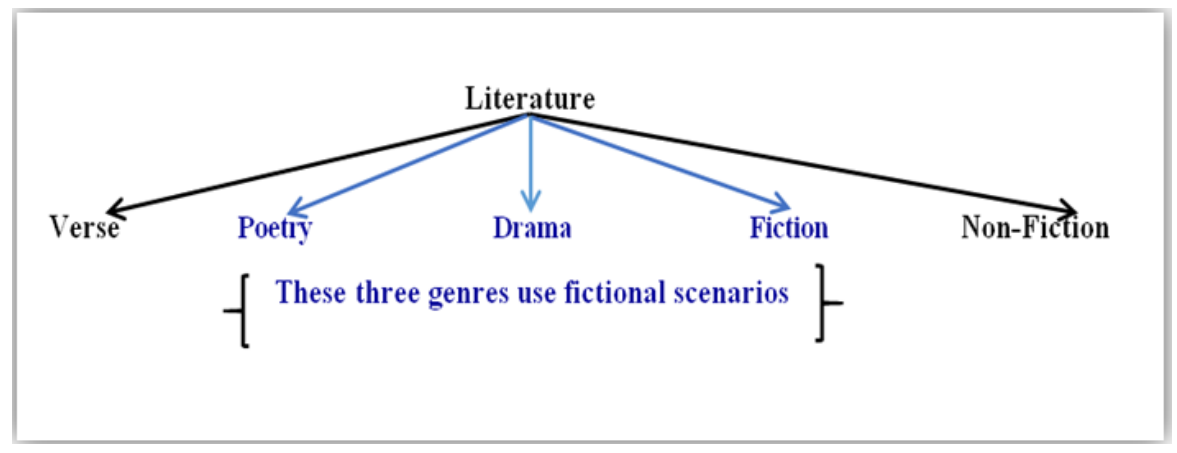

Diagram1.1. The Basic Literary Genres Based on Eagleton's Designation

The Qurān is a unique 'literary genre' which could be located in both the areas of verse and non-fiction. The Qurān uses sublime poetic language without being poetry, and it employs the most convenient narrative techniques used in story-telling without being fiction. This hints at the core distinction between poetry and verse and between fiction and non-fiction. Neither poetic language nor poetic devices alone make poetry. By the same token, the use of narrative techniques in itself does not make the distinction between fiction and non-fiction in literature. There is one significant dimension that sets the basic difference between poetry and fiction on one hand, and verse and nonfiction on the other hand: use of 'fictional scenarios'. Fictional scenarios occur when a literary genre departs from real to imaginary worlds. This is what poetry and fiction do as both add to reality rather than just merely describe it. The basic fact about the Qurān is that the whole text is about real worlds, be it the world of the Unseen, the Hereafter, or a remote world about historical events and figures. I believe that the heated controversy witnessed throughout the history of Islamic thought over whether the Qurān uses 'metaphor' or not is virtually about the use of 'fictional scenarios' rather than the use of 'metaphor' as a linguistic and literary device. On discussing the earlier meanings of the term 'literature' in English, Eagleton (2003) maintains that "what made a text 'literary' was not 
whether it was fictional ... but whether it conformed to certain standards ... The criteria of what counted as literature, in other words, were frankly ideological" (p. 15). This notion is valid with reference to the controversy in hand. Decision on which uses of language are metaphorical or 'fictional' is an ideological question.

\subsection{Questions of the Study}

This research article aims to explore and critically examine nine cases of translating the Qurān into English where traces of ideology are explicitly or implicitly involved in creating fictional scenarios. Specifically the article attempts to answer these two broad questions:

1. To what extent do traces of ideology contribute to producing fictional scenarios in translating the Qurān into English?

2. To what extent do fictional scenarios shape the Qurānic message in English in the light of the ninecases investigated in this article?

\section{METHOD}

\subsection{Study Design}

This study employs a 'Critical Discourse Analysis' (henceforth, CDA) approach for the analysis of relevant data. CDA is a "domain of CRITICAL APPLIED LINGUISTICS" where the "relationship between language, power, and ideology is a crucial focal point" (Tavakoli, 2013, p. 129). CDA is used here within the article's qualitative framework which is "fundamentally interpretive", allowing research outcome to be "ultimately the product of the researcher's subjective interpretations of data" (Dörnyei, 2007, p. 39).

\subsection{Corpus of the Study}

Elventexts (nine cases) are purposively selected from twentyversions of the Qurān in English in this article. Versions included are listed below:

- Abdel Haleem, M. S: The Qurān

- Ahmed, A.: Al-Qurān: a Contemporary translation

- Ahmed, S.: The Qurān as it Explains itself

- Ali, M. M.: The Holy Quran - Arabic Text, English Translation and Commentary

- Ali, S.: The Holy Quran: Arabic Text and English Translation

- Al-Muntakhab: English Translation of The Holy Qur'an, based on the Al-Muntakhab Tafsir written by a group of Scholars

- Asad, M.: The Message of the Qurān

- Haque-Khan: Kanz-ul-Eeman

- Hulusi-Atalay: Decoding the Qurān: a Unique Sufi Interpretation

- Khan, M.Z.: The Quran: The Word as revealed by Muhammad

- Khan, W.: The Quran

- Moeinian, B.:An Easy to Understand Translation of Qur'an

- Monotheist Group: The Qurān: a Monotheist Translation

- Muhammad, I.: Quran: Interpreted by Members of the Imam W.D. Mohammed Community

- Omar-Omar: The Holy Qurān

- Qadri, T.: Irfan-ul-Qurān

- Tarazi, O. Allah's Word in Plain English

- Turner-Behbudi: The Quran: A New Interpretation: In English with Arabic Text 
- Yuksel, al-Shaiban and Schulte-Nafeh: A Reformist Translation of the Qurān

- Zidan-Zidan: The Glorious Qurān: Text and Translation.

Cases in this article consist of one or multiple texts of varying lengths. Droge's translation is used as a control version. The selection of Droge's version here is based on some of the version's characteristic features. The text of the translation itself, not the annotations, is fairly freeform ideological bias and faithfully reflects the SL text as far as the act of translation allows that. Droge employs an essentially literal approach in translating the Qurān and the reader is brought somewhat closer, in terms of structure and lexical selection, to the feel of the original SL text. In the preface to his translation, Droge (2013) maintains that my translation aims not at elegance but strives for as literal a rendering of the Arabic as English will allow. In this way, it is hoped, readers will gain access to the Qurān's distinctive idiom- its 'voice' as it were- in a rendition that seeks to remain close to the way it was originally expressed (p. vii).

\section{RESULTS AND DISCUSSION}

\section{Case (1)}

The first case explored in this article shows how fictional scenarios in translating the Qurān may alter particular verses in order to explain away some aspects of meaning the translators could not accommodate into their ideological schemata. The case isolated hereis a byword of ideology-translation mapping which has a drastic effect on the Qurānic message.

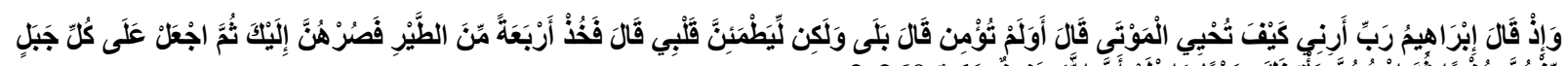

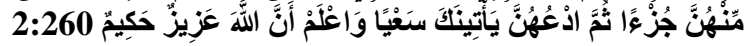

\begin{tabular}{|l|l|}
\hline Control Version & $\begin{array}{l}\text { (Remember) when Abraham said, 'My Lord, show me how You give the dead life.' He } \\
\text { said, 'Have you not believed?' He said, 'Yes indeed! But (show me) to satisfy my heart.' } \\
\text { He said, 'Take four birds, and take them close to you, then place a piece of them on each } \\
\text { hill, (and) then call them. They will com rushing to you. Know that God is mighty, wise.' }\end{array}$ \\
\hline
\end{tabular}

The control version is a faithful echo of the SL text which is a very concise and dense verse that makes use of implicature (the inference-based gap-filler of what is literally said and what is indirectly communicated) to convey a core aspect of meaning in the narrative. Nonetheless, most of the translations of the Qurān in English use the strategy of expansion to explicate what is implicitly conveyed:

\begin{tabular}{|l|l|}
\hline Malik, F & $\begin{array}{l}\text { Yet another example is when Abraham said: "My Lord! Show me how you give life to the dead." } \\
\text { He replied: "Have you no faith in this?" Abraham humbly submitted: "Yes! But I ask this to } \\
\text { reassure my heart." Allah said: "Take four birds; train them to follow your direction, cut their } \\
\text { bodies into pieces and scatter those pieces on hilltops, then call them back; Allah will bring them }\end{array}$ \\
$\begin{array}{l}\text { back to life and they will come to you right away. Thus you will know that Allah is All-powerful } \\
\text { and Wise." }\end{array}$
\end{tabular}

Malik's version explicates the implicature in the relevant verse through expansion: 'cut their bodies into pieces and scatter those pieces on hilltops'. This illustrates a case of tolerable interpretation that builds on the contextual aspects of the SL text. Yet, some versions handle this verse in a way that produces fictional scenarios motivated by the authors' ideological readings of the Qurān.

Consistentwith his Qadyani creeds, Maulana Muhammad Ali, a key figure of the Qadyani movement and one of the earliest insider translators of the Qurān, produces an ambiguous and controversial version:

\begin{tabular}{|l|l|}
\hline Ali, M. M. & $\begin{array}{l}\text { And when Abraham said, My Lord, show me how Thou gives life to the dead, He said: Dost thou } \\
\text { not believe? He said: Yes, but that my heart may be at ease. He said: Then take four birds, then } \\
\text { tame them to incline to thee, then place on every mountain a part of them, then call them, they will } \\
\text { come to the flying; and know that Allah is Mighty, Wise. }\end{array}$ \\
\hline
\end{tabular}

In his commentary on this verse, Ali (1973) precisely disambiguates his translation as follows:

If he [Abraham] should take four birds and tame them, they would obey his call and fly to him even from distant mountains. If the birds, then, obey his call, he being neither their master nor the author of their existence, would not nations submit to the call of their Divine Master and the Author of their existence (p. 115)? 
Later, almost all the Qadyani translators follow in the footsteps of Maulana Muhammad Ali's version but with more explicit language that cancels the implicature in the Qurānic verse in order to reject the miracle implicated. This leads to a fictional scenario that drastically alters the meaning of the SL text:

\begin{tabular}{|l|l|}
\hline Ali, S & $\begin{array}{l}\text { And remember when Abraham said, 'My Lord, show me how THOU givest life to the dead.' God } \\
\text { said, 'Dost thou not believe?' Abraham said, 'Yes, but I ask this that my heart may be at ease.' God } \\
\text { answered, 'Take four birds and make them attached to thee. Then put each of them on a hill; then } \\
\text { call them; they will come to thee in haste.' And know that ALLAH is Mighty and Wise. }\end{array}$ \\
\hline $\begin{array}{l}\text { Omar- } \\
\text { Omar }\end{array}$ & $\begin{array}{l}\text { And (recall the time) when Abraham said, 'My Lord! Show me how You give life to the dead.' } \\
\text { (The Lord) said, 'Do you not believe (that I can)?' He said, 'Yes I do, but (I ask this) that my mind } \\
\text { may be at peace.' (The Lord) said, 'Take four birds and make them attached to you, then put them } \\
\text { each on a separate hill, then call them, they will come to you swiftly. And know that Allah is All- } \\
\text { Mighty, All-Wise.' }\end{array}$ \\
\hline Khan, M.Z & $\begin{array}{l}\text { Call to mind when Abraham supplicated: Lord, show me how dost Thou bring the dead to life. } \\
\text { Allah said: Hast thou not believed? Said Abraham; Indeed, I have believed; but I have asked this } \\
\text { question that my mind may be comforted. Said Allah: Well, then, take four birds and train them to } \\
\text { be attached to thee. Thereafter put each one of them on a hillock. Then call them; they will hasten } \\
\text { towards thee. Know then that Allah is Mighty, Wise. (261). }\end{array}$ \\
\hline
\end{tabular}

ThisQadyani ideological perspective is fervently defended by Shah's (2011) comparison of the Qadayni versions with A. Y.Ali and Ansari-Maududi's translations (two versions produced in the Indian Su-Continent). Shah claims that whereas the Qadynai version "brings out this verse as a teaching to make friends and influence people", Ali and Maududi“s translations "aim at scattering minced meat of birds on different hilltops and then hope for a miracle, never seen before and without any hope for future fruition of minced meat changing into living birds!" Shah further mocks Ali and Maududi's injudicious literal and concrete rendering of this verse, stating that it will "make the Word of God, into a joke". However, it seems that the 'real joke' is embodied in the scenario in which the Prophet Abraham (PBUH) would ask Allah how could He give life to the dead and bring them to life again, and Allah would ask him to try this exercise of training four birds to come to him on call. Surely, Allah would have been mocking Abraham if the scenario had been so. Plus, there would have been no reason to narrate this insignificant experience in the Qurān.

Yet, these Qadyani perspectives are paralleled by similar or identical readings in the modernist and the neoMutazilite versions and interpretations among mainstream Muslims:

\begin{tabular}{|l|l|}
\hline Asad,M. & $\begin{array}{l}\text { And, lo, Abraham said: "O my Sustainer! Show me how Thou givest life unto the dead!" Said } \\
\text { He: "Hast thou, then, no faith?" (Abraham) answered: "Yea, but [let me see it] so that my heart } \\
\text { may be set fully at rest." Said He: "Take, then, four birds and teach them to obey thee; then } \\
\text { place them separately on every hill [around thee]; then summon them: they will come flying to } \\
\text { thee. And know that God is almighty, wise." }\end{array}$ \\
\hline Khan,W. & $\begin{array}{l}\text { When Abraham said, Show me, my Lord, how You revive the dead! God said, Do you not } \\
\text { believe? Abraham answered, Yes, indeed I do believe, but just to reassure my heart. Then God } \\
\text { said, Take four birds, and train them to come back to you. Then place them separately on each } \\
\text { hilltop, and call them: they will come flying to you. Know that God is almighty and wise. }\end{array}$ \\
\hline $\begin{array}{l}\text { Abdel } \\
\text { Haleem, M.S. }\end{array}$ & $\begin{array}{l}\text { And when Abraham said, 'My Lord, show me how You give life to the dead,' He said, 'Do you } \\
\text { not believe, then?' 'Yes,' said Abraham, 'but just to put my heart at rest.' So God said, 'Take } \\
\text { four birds and train them to come back to you. Then place them on separate hilltops, call them } \\
\text { back, and they will come flying to you: know that God is all powerful and wise.' }\end{array}$ \\
\hline Ali, A & $\begin{array}{l}\text { Remember, when Abraham said: "O Lord, show me how you raise the dead," He said: "What! } \\
\text { Do you not believe?" "I do," answered Abraham. "I only ask for my heart's assurance." (The } \\
\text { Lord) said: "Trap four birds and tame them, then put each of them on a (separate) hill, and call } \\
\text { them, and they will come flying to you. Know that God is all-powerful and all-wise." }\end{array}$ \\
\hline $\begin{array}{l}\text { Hulusi } \\
\text { Atalay }\end{array}$ & $\begin{array}{l}\text { And recall when Abraham said, "My Rabb, show me how you give life to the dead". His Rabb } \\
\text { said, "Have you not believed?" (Abraham) said, "Yes, but for my heart to be satisfied (I want to } \\
\text { witness it)..." "Take four types of birds and train them so they grow accustomed to you, then } \\
\text { place each of them upon four different hilltops and call them to yourself. They will come } \\
\text { running (flying) to you. Know that Allah is the Aziz, the Hakim." }\end{array}$ \\
\hline
\end{tabular}


El Mallah (2011) maintains that the case of translating this verse shows "how translators may take advantage of the metaphorical language of the Qurān to move the text towards an interpretation that better serves their own ideologies..." (p. 341). However, rather than being a question of using metaphor, this case involves the processing of implicature in the context of this Qurānic verse. It is obvious here that traces of ideology do cancel the implicature of the verse to create a fictional scenario quite removed from the facts of the SL text. This seems to be in line with the 'reformist' project which has gained ground in interpreting and translating the Qurān since the dawn of the $20^{\text {th }}$ century. Muhammad Abduh and Rashid Ridha, two of the prominent figures of the modernist movement in the Middle East, doubt and degrade the mainstream Muslim interpretation of this verse which is adopted by almost all earlier exegetes. Abduh and Ridha vehemently adopt Abu Muslim's (an earlier staunch Mutazilite) interpretation which argues against the miracle implicated in the verse. The discussion of the relevant verse in Tafseer Al-Manar (Vol. 3, pp. 55-58) ends with a word of admiration of Abu Muslim for his 'meticulous' and 'unorthodox' reading of the relevant text:

$$
\text { "ولله در أبي مسلم ما أدق فهمه وأثد استقلاله فيه" (رضا، 1947، جزء 3، ص 58). }
$$

"How marvelous was Abu Muslim in his meticulous and independent understanding."

Aware of the absurdity of the fictional readings above, Ahmed Shabir provides his own fictional scenario which builds on some sort of analogy that is further removed from the SL text and context:

\begin{tabular}{|l|l|}
\hline Ahmed, S. & $\begin{array}{l}\text { Abraham wanted to understand the Law of Revival of nations. Allah asked him if he believed } \\
\text { that it were possible. Abraham said he believed but that he wanted a practical example to } \\
\text { educate his heart and mind. Allah told him to take four birds and train them in a kind manner, } \\
\text { and then to leave them far apart on each hilltop. And then call them; they will come in haste. (At }\end{array}$ \\
$\begin{array}{l}\text { one call of Abraham, those birds came flying back to him. This is how mankind can be brought } \\
\text { to the Word of Allah with decent training, giving them a new life). Know that this Wisdom } \\
\text { comes to you from Allah, the Almighty, the Wise. }\end{array}$ \\
\hline
\end{tabular}

Ahmed writes his own version which builds on his own concept of tasreef in interpreting the Qurān. Nevertheless, Ahmed's peculiar interpretation has its roots in Maulana Muhammad Ali's (1973) arguments against a particular instance of the Biblical account of Abraham's story.

Another group that picks Ahmed's fictional scenario is Imam W. D. Mohammed Community in North America:

\begin{tabular}{|l|l|}
\hline Muhammed, & $\begin{array}{l}\text { Behold, Abraham said, "My Lord, show me how You give life to the dead." He said, "Do you } \\
\text { not believe?" He said, "I do, but show me to satisfy my heart." He said, "Take four birds and } \\
\text { train to return to you. Puta part of them on every hill and call to them. They will come to you } \\
\text { with speed. So know that God is Exalted, Wise. }\end{array}$ \\
\hline
\end{tabular}

Uqdah (2010), one of Imam Mohammed's disciples, maintains that the four birds are placed on four hills (a part is one bird on each hill). The hill in the teaching of Imam Mohammed "represents authority", "stability and structure". He further explains thatAllah tells Abraham to call the birds and they will fly to him with great speed. "Abraham's call represents the breath (wind) of inspiration that Allah used when creating Adam and Jesus used when creating a bird"

Nonetheless, there is a version which is in direct opposition to all these translations that negates the miraculous event narrated in the Qurānic verse. Turner-Behbudi's version introduces his own peculiar fictional scenario which is quite removed from the facts of the SL text as well:

\begin{tabular}{|l|l|}
\hline $\begin{array}{l}\text { Turner- } \\
\text { Behbudi }\end{array}$ & $\begin{array}{l}\text { And bring to mind the astonishment of Abraham on passing a corpse, half-eaten by wild } \\
\text { animals. Abraham, his heart full with doubts, said: "O Lord! Show me how you give life to the } \\
\text { dead!" God said: "Do you not believe in the Resurrection?" Abraham said: "Yes- but show me } \\
\text { how it is done so that I may gain greater conviction." God said: "Hunt four birds, roast them } \\
\text { and then eat them, so that their flesh becomes one with yours. Then take the remaining flesh }\end{array}$ \\
\hline $\begin{array}{l}\text { and bones and scatter them on the hills. When you have done this, call them to you: they will } \\
\text { fly to you, restored completely. Know that God is Almighty, All-Wise." }\end{array}$ \\
\hline
\end{tabular}

The story of Abraham's passing a corpse half-eaten by wild animals, hunting four birds to be roasted and then eaten so that their flesh would become one with Abraham, and then taking the remaining flesh and bones and scattering them on the hills belongs to a work of fiction not to the relevant Qurānic verse. This mixing of the word of Allah with some fictional narratives common in Qurānic exegeses results from Behbudi's Shi'i background where the distinction between the divine and the human is often blurred and misty (Sideeg, 2014). 


\section{Case (2)}

Like the first case, the second one reflects the impact of the neo-Mutazilite and pseudo-scientific perspectives on interpreting and translating the Qurān.

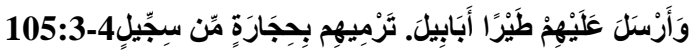

\begin{tabular}{|l|l|}
\hline Control Version & He sent against them birds in flocks, (which) were pelting them with stones of backed clay. \\
\hline Ali, A & $\begin{array}{l}\text { And sent hordes of chargers flying against them, (While) you were pelting them with stones } \\
\text { of porphyritic lava, }\end{array}$ \\
\hline Ahmed, s. & $\begin{array}{l}\text { And sent upon them swarms of flying creatures. Then you showered them with hard stones } \\
\text { earmarked with requital. ('Sijjil' = Inscribed = Marked out). }\end{array}$ \\
\hline
\end{tabular}

Both Ali's and Ahmed's version switch the act of destroying the invading army from 'birds' to 'men', creating a fictional scenario which the Qurānic text never accommodates. The question is why these versions switch the act of destroying the invading army from 'birds' to 'men', creating a drastically different version from almost all the versions of the Qurān available in English. The answer lies in the authors' ideological agendas which reject the phenomenon of miracles. This is why Ahmed (2012) invents his own story of the whole scene to create a fictional scenario, the kind of which the history of Qurānic exegesis has never witnessed before:

As Abrahah's army approached Makkah, the Makkans who had been alerted by some travelers beforehand, saw flocks of birds that normally fly over caravans in search for food. The Makkans mounted the hills around and threw stones on the troops. The elephants, and in turn, other rides panicked and trampled the soldiers (p. 612).

Here Ahmed claims that "birds normally fly over caravans in search of food."If it were a normal phenomenon according to Ahmed's fictional scenario, then why Allah had have chosen to narrate a story which is as normal as other stories? And why Allah then credits Himself with the act of destroying this army in the Sura?: "Have you not seen what your Lord did with the Companions of the Elephant?" There is a plethora of normal events that had happened in those days; why does the Qurān only narrates this insignificant story?

Again it should be stated that Ali's and Ahmed's versions above have their roots in the modernist and neoMutazilite agendas which have prevailed in the Middle East and the Indian Sub-Continent since the last decade of the $19^{\text {th }}$ century and the dawn of the $20^{\text {th }}$ century. Muhammad Abduh and Rashid Ridha have had a significant effect on the traditions of Qurānic exegeses. They are both reformist who have strong tendency to prove that Islam is a rational religion which conforms to the prevailing positivist perspectives in their age. This does lead them to extreme positions to the extent that they state:

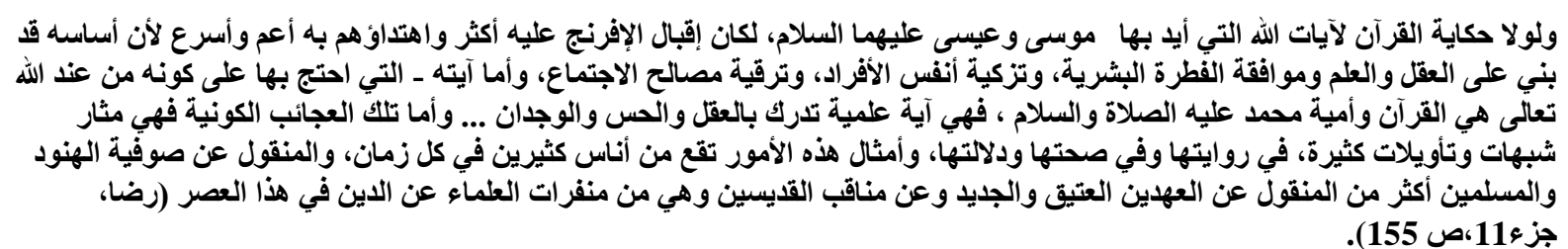

Hadn't the Qurān narrated Allah's miracles given to Moses and Jesus [PBUT], more Westerners would have universally embraced the teaching of Qurān faster. The essential Qurān is based on intellect and science, in harmony with the sound intuition, and intended to purify the individuals and promotes the society. The sign that he [Muhammad (PBUH)] is a prophet of Allah is the Qurān itself and the fact that he is illiterate. It is a sign that could be perceived through reason, senses, and affection. As for those supernatural miracles, they are the source of doubts and ambiguous interpretations regarding both their authenticity and significance. A plethora of such miracles have been claimed at different times, and what is attributed to the Indian and Muslim Sufis exceeds what is narrated in the Old and New Testaments or attributed to saints. Nonetheless, these miracles constitute the reason for scientists to turn away from religion in this era.

Case (3)

This case exposes an ideological reading of some verses which are said to confirm the harmony between the Qurān and current scientific theories. This leads to peculiar fictional scenarios that have significant impact and implications on interpreting the Qurān:

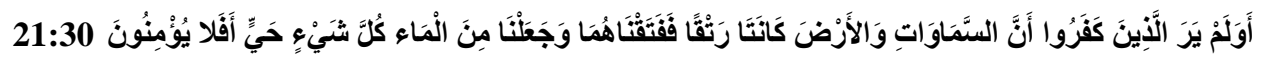




\begin{tabular}{|l|l|}
\hline Control Version & $\begin{array}{l}\text { Do those who disbelieve not see that the heavens and the earth were (once) a solid mass, } \\
\text { and we split them apart, and we made every living thing from water. Will they not } \\
\text { believe? }\end{array}$
\end{tabular}

Undoubtedly the Qurān narrates cosmic facts about the universe and the beginning of life on earth. Nevertheless, some modernist versions introduce 'fictional' readings that attempt to incorporate some current theories about the origin of the universe into the Qurānic exegesis. These modernist readings attempt to show the harmony between the Qurān and modern science in order to prove the divine origin of the Book of Islam. The texts discussed in this case represent this trend:

\begin{tabular}{|l|l|}
\hline Moeinian, B & $\begin{array}{l}\text { Are those who have chosen the disbelief not aware of the fact that at the beginning } \\
\text { everything in the universe was densely concentrated (so concentrated that could pass } \\
\text { through the eye of a needle, then I exploded it into existence? } 1 \text { Do they not know that I } \\
\text { have created everything living species from the water? What is their excuse now in order } \\
\text { to choose the disbelief? }\end{array}$ \\
\hline
\end{tabular}

Moeinian's version reflects the modernist perspectives which attempt to interpret the Qurān in terms of modern scientific theories. The version above is based on a 'pseudo-conception' of the 'Big Bang' theory which claims that the world originated from a single quantum, which was squeezed into a dense dot of pure energy that could pass through the eye of a needle but would expand everlastingly. In translating another verse, Moeinian explicitly declares the 'Bing Bang' theory to be a Qurānic commodity:

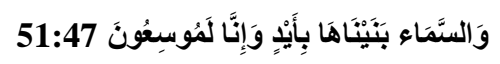

\begin{tabular}{|l|l|}
\hline Moeinian, B & $\begin{array}{l}\text { I (God) have created the universe myself and will continue to expand it [confirmation of } \\
\text { the expansion theory of the universe after the Big Bang.] }\end{array}$ \\
\hline
\end{tabular}

It is a fact that Moeinian's translation echoes a growing tendency among modernist scholars and some apologists who seek to establish the miraculous nature of the Qurān on the premise that if new discoveries have already been in the Qurān, this will confirm its divine origin. However, the dilemma of this approach is that it attempts to "correlate" the "transient" scientific theories with the "perennial wisdom and truth of the Qurān" (Rehman, 2003, p. 4). This is usually done by decontextualizing the relevant verses as illustrated in the text below:

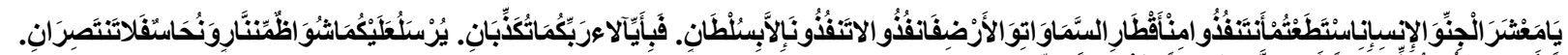

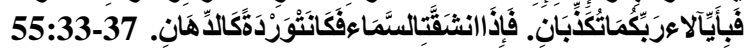

\begin{tabular}{|l|l|}
\hline Control Version & $\begin{array}{l}\text { Assembly of jinn and humankind! If you are able to pass beyond the confines of the } \\
\text { heavens and the earth, pass! You will not pass beyond (them) except by authority. Which } \\
\text { of the blessings of your Lord will you two call a lie? A flame of fire and a furious wind } \\
\text { will be sent against you, and you will not (be able to) defend yourselves. Which of the } \\
\text { blessings of your Lord will you two call a lie? When the sky is split open and turns like oil }\end{array}$ \\
\hline
\end{tabular}

Here Moeinian incorporates a plethora of current 'scientific theories'and 'science fiction'in translating this verse:

\begin{tabular}{|l|l|}
\hline Moeinian, B & $\begin{array}{l}\text { O' you men and Jinns (extra-terrestrials), you cannot travel beyond the boundaries of earth } \\
\text { into the space without the power (of knowledge) given to you by God. Which } \\
\text { manifestation of your Lord's grace do you (men and extraterrestrials) deny? You will be } \\
\text { bombarded by the projectiles of fire and metals which you cannot pass through [without } \\
\text { the great power]. Which manifestation of your Lord's grace do you (men and } \\
\text { extraterrestrials) deny? The Day that the [ozone layer of the] sky is cracked down and its } \\
\text { color is changed into red. }\end{array}$ \\
\hline
\end{tabular}

Inter-textual and intratextualreadings of the SL text reveal that these verses have nothing to do with the 'science fiction' of "extra-terrestrials", or arguments on 'space travel' and the 'ozone hole' which Moeinian inserts into the verse, creating a bizarre fictional scenario. Muhammad Al-Tahir Ibn Ashur (1879-1973), one of the most reliable recent sources on Qurānic exegesis, comments on these verses as below:

"هذا مقول محذوف يدل عليه سياق الكلام السابق واللاحق وليس خطابا للإنس والجن في هذه الحياة الدنيا" (ابن عاشور، 1984، جزء 27، ص

"This is an omitted utterance indicated by the context of what comes before and after it; it is not an address intended for humans and jinn in this life". 
The paradox is that those who interpret these verses according to the scientific claims produce two opposing perspectives:

1. The verse is a proof that 'space travel' is impossible. This was the prevailing interpretation before space travels were launched by the mid- $20^{\text {th }}$ century.

2. The verse is a proof that the Qurān predicts human space flight. They maintain that the word 'authority' in the verse could be understood to mean 'knowledge'. This is the current interpretation after space travels were launched.

This paradoxical instance exposes the incoherence of the scientific miracles narrative in interpreting and translating the Qurān. There is no valid justification for dismissing valid and simpler interpretations of the relevant verses in the Qurān in favor of controversial and ambiguous ones based on ever-changing theories. The invalidity the narrative of the scientific interpretation of the Qurān has its roots in the fact that the Qurān and science are entirely distinct sources of knowledge in terms of their ontologies, methods, and goals. This is why what science has discovered could not be taken as the ultimate meaning of the Qurān. Undoubtedly, there are some broad allusions in the Qurān to some cosmic phenomena. But these allusions could not be targeted as the proof of the Qurān miraculous nature and divine origin. Yet, the tendency to use these allusions as the ultimate guide of interpreting the Qurān is not new. Al-Shatibi, one of the eminent Muslim scholars of the $14^{\text {th }}$ century, argues for the invalidity of the very notion of interpreting the Qurān in the light of scientific theories. At the end of his well-grounded argument, Al-Shatibi succinctly maintains that

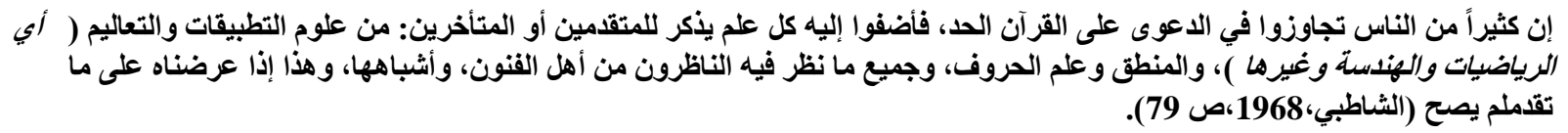

Many people have exceeded all limits concerning the scope of the Qurān as they attributed to it all types of knowledge of both ancient and contemporary scholars: theory and practice [in mathematics, geometry, etc.], logic, philology, and all walks of arts studied by scholars and related disciplines. When all this is scrutinized in the light of what we have already discussed, it proves to be entirely invalid.

\section{Case (4)}

The fourth case would further illustrate the type of fictional scenarios which result from ideological readings that subject interpreting the Qurān to the human knowledge based on the current scientific theories:

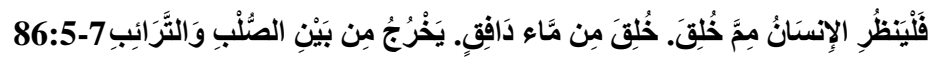
\begin{tabular}{|l|l|}
\hline Control Version & So let the human consider: what was he created from? He was created from spurting water.
\end{tabular} It comes forth from (a place) between the spine and the ribs.

This verse has been a source of debate through the whole history of Qurān exegesis. Al-Tabari, the most prominent classical exegetist, documented the diversity of interpretations of the relevant verse. His choice is that the 'gushing water' in this verse refers to both 'man' and 'woman'.(الطبري، 19، جزء 24، ص 292-296)

Though inconsistent with the linguistic facts of the text, Al-Tabri's choice is adopted by other prominent classical and modern exegetists such as Ibn Kathir, Al-Qurtubi, and Al-Shinqeeti. Yet, in all these choices, the paramount factor is the linguistic aspect of the text and not any other consideration.

However, in line with his method of tasreef which does always result in peculiar fictional scenarios, Ahmed Shabir, a Qurānist and a staunch modernist advocating extreme positions on interpreting and translating the Qurān, produces a version that naively alters the SL text against all the linguistic and contextual clues contained in the SL text:

\begin{tabular}{|l|l|}
\hline Ahmed, S. & $\begin{array}{l}\text { Let the human being, then, consider out of what he has been created. (And realize the } \\
\text { common origin of all mankind. Has there not passed over man an era when he was not } \\
\text { even worth mentioning? He has been created from a turbulent water. That issued from } \\
\text { between tough rocks and mingled dust. }\end{array}$ \\
\hline
\end{tabular}

None of the exegetists in the long and diverse timeline of the interpretation of the Qurān has ever alluded to this scenario adopted in Ahmed's version which builds on the theory of evolution. A second version which strives to give a scientific atmosphere to this verse is Moeinian's translation: 


\begin{tabular}{|l|l|}
\hline Moeinian, B. & $\begin{array}{l}\text { O' mankind, God is asking you to think for a while from what you are created. From a tiny } \\
\text { insignificant sperm [that may be seen only with a powerful microscope] created between } \\
\text { the back bone and the rib. }\end{array}$ \\
\hline
\end{tabular}

Al-Muntakhab version, which always attempts to subject the Qurān to the current scientific theories and interpretations, alters this verse to avoid its assumed incompatibility with modern science:

\begin{tabular}{|l|l|}
\hline Al-Muntakhab & $\begin{array}{l}\text { Let man ponder from what was he created! He was created from fluid that is simply } \\
\text { emitted and ejaculated. He -man- issues forth at birth from the space between the bony } \\
\text { pelvis and the breast-bone, the course that is normally negotiated. }\end{array}$ \\
\hline
\end{tabular}

Though debates over this subject shows the weak position of the trend of interpreting the Qurān in the light of current theories, Maurice Baucaille's seminal work 'La Bible, le Coran et la Science' has ignited the tendency and the fervor to handle the Qurān within the trend of this 'scientism'. In discussing the verse above, Baucaille (1976, 2003) has a detailed commentary on it:

Two verses in the Qurān deal with sexual relations themselves. They are described in terms which unite the need for precision with that of decency. When translations and explanatory commentaries are consulted however, one is struck by divergences between them. I have pondered for a long time on the translation of such verses, and am indebted to Doctor A. K. Giraud, former Professor at the Faculty of Medicine, Beirut, for the following: Sura 86, verses 6 and 7:

"(Man) was fashioned from a liquid poured out. It issued (as a result) of the conjunction of the sexual area of the man and the sexual area of the woman" (p. 137).

Baucille's choice is the genesis of Asad's version. It seems that Asad picks the hint from Baucille to mix it with the interpretations adopted by earlier exegetes to craft his own version:

\begin{tabular}{|l|l|}
\hline Asad, M. & $\begin{array}{l}\text { LET MAN, then, observe out of what he has been created: he has been created out of a } \\
\text { seminal fluid issuing from between the loins [of man] and the pelvic arch [of woman]. }\end{array}$
\end{tabular}

Furthermore, Zidan and Zidan's version of the Qurān in English, which was produced in 1989 and later approved by Al-Azhar Islamic research academy, adopts a faithful replica of Baucille's choice above:

\section{\begin{tabular}{|l|l|l|l}
\hline Zidan-Zidan & (Mankind) was created of a liquid poured out- It issues (as a result) of the conjunction
\end{tabular}} of the sexual area of the man and the sexual area of the woman.

A third version newly produced in North America follows in the footsteps of Baucille:

\begin{tabular}{|l|l|}
\hline Tarazi, $\mathbf{O}$ & $\begin{array}{l}\text { So look at what you were created from. You were created from fluids, brought together } \\
\text { from your mother and father. }\end{array}$ \\
\hline
\end{tabular}

It is quite obvious that Baucille's version has nothing to do with the earlier interpretations made by Al-Tabari and others. Baucille, in his attempt to prove the harmony between Qurān and modern science, opts for a fictional scenario that is removed from both the linguistic and contextual facts of the relevant SL text.

\section{Case (5)}

The fifth case of fictional scenarios explored in this article is about cases related to 'gender-issues'. The texts discussed here indicate that translating the Qurān is significantly affected by the socio-cultural context and ideology of the translator:

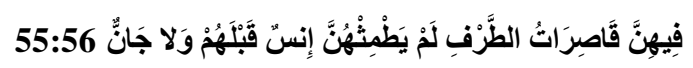

\begin{tabular}{|l|l|}
\hline Control Version & $\begin{array}{l}\text { In them (there are maidens)restraining [their] glances- no man or jinn has had sex with } \\
\text { them before them- }\end{array}$ \\
\hline
\end{tabular}

However, there is one version which uses explicit language that defies the Qurānic stylistics:

\begin{tabular}{|l|l|}
\hline Hilali -Khan & $\begin{array}{l}\text { Wherein both will be those (maidens) restraining their glances upon their husbands, whom no } \\
\text { man or jinn yatmithhunna (has opened their hymens with sexual intercourse) before them. }\end{array}$ \\
\hline
\end{tabular}

In opposition to Hilali-Khan's explicit version, Reformist translation employs a very peculiar lexical selection to produce the most extreme fictional scenario in this context: 
\begin{tabular}{|l|l|}
\hline Reformist Trans. & In them are the best of the fruits hanging low, untouched before by any human or Jinn.
\end{tabular}

Changing 'maiden' into 'fruits' betrays the translators' ideological reading, which tries to downplay any reference to issues involving 'gender' or 'sexuality' in the Qurān. The result is a super-fictional scenario, something that has not been attempted before in the long and rich timeline of Qurānic exegeses. The Reformist translation attempts to produce a fictional reading of the Qurān that is in line with the Western perspectives of gender and other social issues.

\section{Case (6)}

This is a unique 'Qurānist' case as the fictional scenario here illustrates the way the Qurānists do interpret and translate particular verses on Islamic rituals:

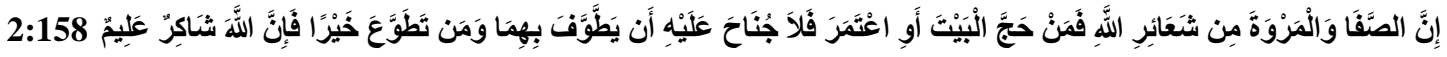

\begin{tabular}{|l|l|l}
\hline Control Version & Surely, al-Safa and al-Marwah are among the symbols of God. Whoever performs
\end{tabular} pilgrimage to the House or performs visitation - (there is) no blame on him if he goes around both of them. And whoever does good voluntarily surely God is thankful, knowing.

The control version echoes almost all translations of the Qurān across various linguistic backgrounds, cultures, ideologies. Nevertheless, Reformist translators (Yuksel and his associates) opt for a version that drastically changes the meaning of this verse:

\begin{tabular}{|l|l|}
\hline Reformist Trans. & $\begin{array}{l}\text { The serenity and chivalry are amongst God's emblems. Therefore, whosoever makes } \\
\text { Pilgrimage to the sanctuary, or is merely passing through, commits no error by } \\
\text { oscillating between them. Whoever volunteers for goodness; indeed God is Appreciative, } \\
\text { Knowledgeable. }\end{array}$
\end{tabular}

It should be noted here that sometimes the Qurānist versions are evolving and changing with the changes of their authors' ideologies. Though Progressive Translation uses the term (Safa) and (Marwah), the Monotheist Translation, produced by the same group of Qurānists, twice alters the verse as cited below:

\begin{tabular}{|l|l|}
\hline $\begin{array}{l}\text { Progressive Trans. } \\
\text { (2003 Version) }\end{array}$ & $\begin{array}{l}\text { The Safa and Marwah are amongst the rites of God. Whomsoever travels to the House for } \\
\text { the Pilgrimage or merely visits, commits no error that he should briefly visit them. And } \\
\text { whoever does good voluntarily, then God is Appreciative, Knowledgeable. }\end{array}$ \\
\hline $\begin{array}{l}\text { Monotheist Trans. } \\
\text { (2011 Version) }\end{array}$ & $\begin{array}{l}\text { The camel and goat heavy with milk are amongst God's decrees. So whosoever makes } \\
\text { Pilgrimage to the sanctuary, or is merely passing through, commits no error that he } \\
\text { should partake of them. And whoever donates for goodness, then God is Appreciative, } \\
\text { Knowledgeable. }\end{array}$ \\
\hline $\begin{array}{l}\text { Monotheist } \\
\text { Trans.(2013 }\end{array}$ & $\begin{array}{l}\text { Indeed, the stone and the rock outcropping are among the symbols of God. So whoever } \\
\text { Version) } \\
\text { traverse them. And whe the Sanctuary, or is merely visiting, commits no error should he }\end{array}$ \\
\hline
\end{tabular}

One may find it impossible to figure out the sources of the insertion of "camel and goat heavy with milk" in the context of translating the relevant verse. However the fictional scenario in the Monotheist Version (2013) exposes the final ideological stance of the Qurānist movement in North America. The Monotheist Group (2012) rejects the Muslim understanding of the rituals of Hajj (pilgrimage to Makkah). This rejection is based on their belief that the location of the pilgrimage is 'Jerusalem', the real Bakka, not Makkah. The Monotheist Group (2012) firmly maintains that

With regards to the Temple area of Jerusalem, if we are looking for two protruding points, then they are easily located. The Temple area has two outcroppings/foundations; the first being the stone upon which lies the 'Dome of the Rock' (hence the name), while the other is a stone upon which a smaller structure has been built known as the 'Dome of the Tablets'. Thus, these two features, both of which have been preserved on the Temple Mount site, can be claimed as the 'Safa' and 'Marwa' (the stone and the rock outcropping) that God has mentioned as being physical elements as part of the site of Pilgrimage are amongst the symbols of God (p. 247).

Musa (2010), herself a Qurānist, admits that the "Free-minds.org, which reflects the Reformist and Monotheist perspectives, rejects the term 'five pillars' of Islam as a "myth". It is not only the question of changing the location of pilgrimage from Mecca to Jerusalem. These two groups maintain that "Muslim shahada is a blasphemous hypocrisy" and that "salat is not ritual prayer" (p.19). 


\section{Case (7)}

This case concerns the translation of reference of some personal pronouns in a SL text that is highly condensed and stylistically complex:

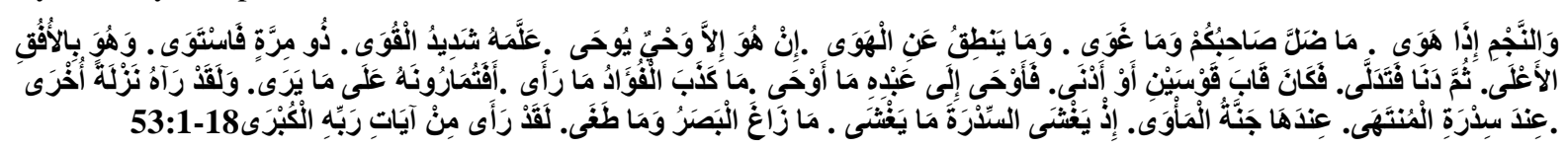

\begin{tabular}{|l|l|}
\hline Control Version & By the star when it falls! Your companion has not gone astray, nor has he erred, nor does
\end{tabular} he speak on a whim. It is nothing but an inspiration. One harsh in power has taught him. One full of strength! He stood poised, while He was at the highest horizon, then He drew near and came down. He was two bow-lengths tall, or nearly. And so He inspired His servant (with) what he inspired. His heart did not lie about what it saw. Will you dispute with him about what he sees? Certainly he saw Him at a second decent, by the Lote Tree of the Boundary, near the garden of the Refuge, when (there) covered the Lote Tree what covered (it). His sight did not turn aside, nor did it transgress. Certainly he saw one of the greatest signs of his Lord.

Almost all the versions investigated in this article echo the Control Version which is essentially a literal and faithful copy of the SL text. For instance, Starvosky's version runs as follows:

- * [I swear] by the star when it sets!

- * Your companion did not lose his way and did not go astray!

- He does not speak for himself,

- But reveals the inspiration that inspired him.

- *He was taught by someone great in power,

- full of wisdom, who stood upright

- In the highest horizon.

- Then he descended and approached

- within two bow shotsornearer,

- *and inspired to His servant what He inspired.

- His heart did not deceive him about what he saw!

- So, why do you argue with him about his vision?

- *He saw [the Spirit] at the second descent

- *by the farthest Sidrah-tree

- *near the Garden of Salvation,

- Bythe Sidrah-tree enshrouded in what enshrouded it.

- His eyes neither strayed nor faltered.

- Verily, he saw the greatest Sign of his Lord!

Nonetheless, there are two versions which present a fictional scenario that reflects the ideological and sectarian readings adopted by their authors. Both Qadri's and Haque-Khan's versions interpret the 'star' as being the Prophet Muhammed (PBUH) without any linguistic or contextual clue. On the contrary, the SL text in using the verb (هَوى) makes it impossible to give this verse this allegorical interpretation used by both these authors. This enhancement of the status of the Prophet Muhammad (PBUH) is a characteristic feature of both versions due to the Sufi (Barelwi) background of both (Robinson, 2007, p. 263). This leads to the two versions' radical departure from the SL text, the Control Version, and almost all translations of the Qurān in English through the invariant use of the pronouns $\mathrm{He} / \mathrm{His}$ in reference to Allah (SWT) in all instances in this text. 


\begin{tabular}{|c|c|}
\hline $\begin{array}{l}\text { Qadri's } \\
\text { Version }\end{array}$ & $\begin{array}{l}\text { By the bright star (Muhammad [blessings and peace be upon him]) when (he ascended during the } \\
\text { Ascension Night in the twinkling of an eye and) descended. He who bestowed on you his } \\
\text { companionship (i.e., the Messenger, who made you his companions by blessing you with his } \\
\text { companionship,) has never lost his way, nor has he (ever) strayed from the right path. And he does } \\
\text { not speak out of his (own) desire. His speech is nothing but Revelation, which is sent to him. (The } \\
\text { Lord) of Mighty Powers (directly) conferred on him (perfect) knowledge, He Who is absolute } \\
\text { beauty. Then He (the Effulgence of Beauty) decided to unveil (Himself). And he (Muhammad } \\
\text { [blessings and peace be upon him]) was on the uppermost horizon (of the realm of creation during } \\
\text { the Ascension Night i.e., on the apex of the created cosmos).Then He (the Lord of Honour) drew } \\
\text { closer (to His Beloved Muhammad [blessings and peace be upon him]) and then drew even closer. } \\
\text { Then a distance measuring only two bow-lengths was left (between Allah Unveiled and His } \\
\text { Esteemed Beloved), or even less than that (in extreme nearness). So (on that station of nearness) He } \\
\text { (Allah) revealed to His (Beloved) servant whatever He revealed. (His) heart did not take it contrary } \\
\text { to what (his) eyes beheld. Do you argue with him about what he saw? And assuredly, he saw Him } \\
\text { (Allah Unveiled) the second time (again and you argue only about seeing Him once). At the farthest } \\
\text { Lote-Tree-Sidra al-Muntaha, Adjacent to that is the Eternal Paradise-Janna al-Ma'wa, When } \\
\text { theophanies (i.e., effulgent disclosures) of the divine light wrapped up al-Sidra (the Lote-Tree at the } \\
\text { Far End), covering it expansively. His eye neither inclined aside nor overstepped the limit; (it gazed } \\
\text { in ecstasy at Whom it was to gaze). Surely, he saw the greatest signs of His Lord (during the } \\
\text { Ascension Night). }\end{array}$ \\
\hline $\begin{array}{c}\text { Haque } \\
\text { and } \\
\text { Khan's } \\
\text { Version }\end{array}$ & $\begin{array}{l}\text { By oath of the beloved shining star Mohammed (peace and blessings be upon him), when he } \\
\text { returned from the Ascent. Your companion did not err, nor did he go astray. And he does not say } \\
\text { anything by his own desire. It is but a divine revelation, which is revealed to him. He has been } \\
\text { taught by the Extremely Powerful. The Strong; then the Spectacle inclined towards him. And he } \\
\text { was on the horizon of the highest heaven. Then the Spectacle became closer, and came down in full } \\
\text { view. So the distance between the Spectacle and the beloved was only two arms' length, or even } \\
\text { less. (The Heavenly Journey of Prophet Mohammed - peace and blessings be upon him - was with } \\
\text { body and soul.) So Allah divinely revealed to His bondman, whatever He divinely revealed. The } \\
\text { heart did not deny, what it saw. (The Holy Prophet was bestowed with seeing Allah) What! So do } \\
\text { you dispute with him regarding what he saw? And indeed he did see the Spectacle again. Near the } \\
\text { lote-tree of the last boundary. Close to which is the Everlasting Paradise. When the lote-tree was } \\
\text { being enveloped, by whatever around it. The sight did not shift, nor did it cross the limits. Indeed he } \\
\text { saw the supreme signs of his Lord. }\end{array}$ \\
\hline
\end{tabular}

Interpreting the falling star as being the Prophet Muhammad (PBUH), use of far-fetched interpretations and additions, and the invariable use of pronouns He/His with reference to Allah (SWT) in the whole text do really constitute a fictional scenario in both Qadri's and Haque-Khan's versions. Robinson (2007) has a detailed commentary on the Barlawi version of Kanzul Iman which translated to English by Haque. He explains the Barlawi Sufi background of this version of the Qurān which focuses on the "enhanced status" of the Prophet (PBUH) and the special significance of the event of m'iraj and the fact that knowledge of the unseen is bestowed on the Prophet at that night. Robinson's comments apply to Qadri's version as well as other similar Sufi translations.

The question whether the Prophet (PBUH) saw Allah (SWT) or not is discussed by Ibn Tayyimia in the light of the narrations and traditions from the early generations of Muslims:

$$
\begin{aligned}
& \text { و وأما الرؤية، فالذي ثبت في الصحيح عن ابن عباس أنه قال: "رأى محمد ربه بفؤ اده مرتين" و عائشة أنكرت الرؤية. فمن الناس من جمع بينهما }
\end{aligned}
$$

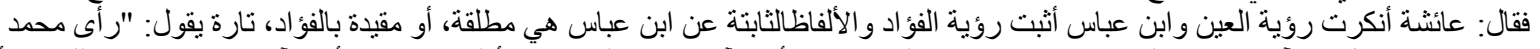

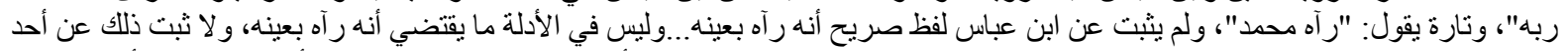

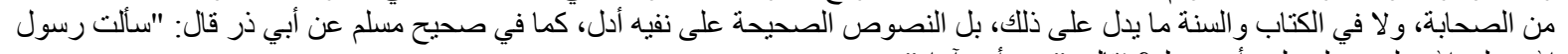

$$
\begin{aligned}
& \text { الله صلى الله عليه وسلم هل رأيت ربك؟ فقال: "نور أنى آراه" }
\end{aligned}
$$

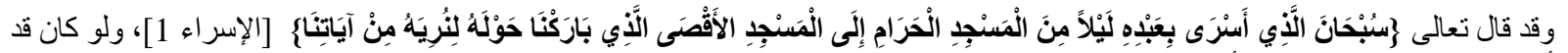

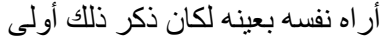

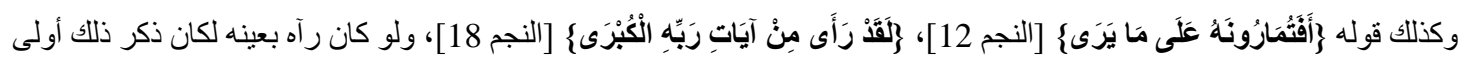

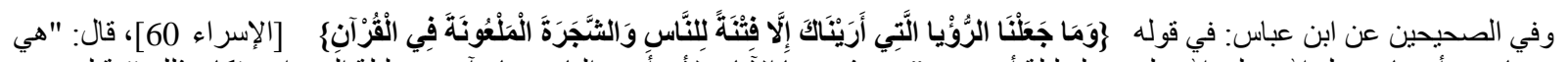

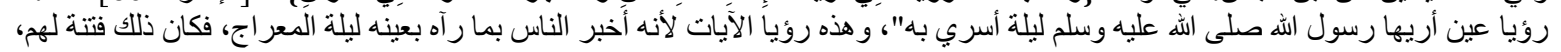


As for seeing Allah (SWT), the authentic narration from Ibn "Abbas is that he said "The Prophet Muhammad saw Allah twice in his heart twice", whereas 'Aisha denied it. Some scholars reconciled Ibn "Abbas's and 'Aisha's point of views stating that 'Aisha denied the eye vision and Ibn 'Abbas confirmed seeing in the heart. The authentic narrations from Ibn 'Abbas are somehow undefined, or restricted to seeing in the heart. He on one instance said "Muhammad saw his Lord", on another 'Muhammad saw him'. No authentic report from 'Ibn Abbas contains the phrase that the Prophet saw Allah with his own eyes. Plus, there is no evidence in all authentic narrations from the Prophet's companions and the Qurān and Sunnah supporting that. On the contrary, authentic weighty narrations tell the opposite. As narrated in Saheeh Muslim by Abu Dhar saying: "I asked Allah's Messenger (PBUH) 'Did you see your Lord? 'How can I see Him since there was a light)" In another narration, the Prophet said."”

Allah (SWT) says [Exalted is He who took His Servant by night from al-Masjid al-Haram to al-Masjid al- Aqsa, whose surroundings We have blessed, to show him of Our signs. Indeed, He is the All-Hearing, the All-Seeing.] Had Allah (SWT) shown His Own Self to the Prophet (PBUH), He would have narrated that most significant event in the Qurān.

In the two Saheehs, it is narrated that Ibn 'Abbas, commenting on the relevant verse, said, "It is what Allah's Messenger saw in the Night of Israa and M'iraj". It is about the vision, signs and miracles in that night, which was a trail for them. Some of them believed it, whereas some denied it. However, he did not tell them that he saw Allah (SWT) with his eyes. All narrations on the Prophet's Ascension do not mention this event. Had it happened, the Prophet would have mentioned it.

The claim that the Prophet (PBUH) saw Allah (SWT) with his own eyes is quite feeble and entirely baseless on both textual and logical levels. Had the Prophet Muhammad (PBUH) seen Allah (SWT), this would have been the most significant event in the timeline of Islam and the greatest cosmic event which would not be narrated only in short and ambiguous texts. The notion that Prophet Muhammad [PBUH] attained the Beatific Vision in the Night of the Ascension belongs to the world of fiction not a reality in the Qurān.

Case (8)

The desire to intrude into the sexual privacy of women is an ideological perspective which creates fictional scenariosfar-removed from the reality of SL texts and far-removed the atmosphere of the Qurānic discourse.This is manifested in Turner-Behbudi's translation of this part of the story of Maryam (Mary):

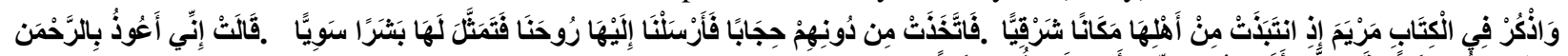

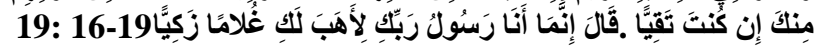

Control Version echoes the majority of translations investigated. Plus, Control Version seems to be a faithful echo of the Qurānic text. Nonetheless, Turner-Behbudi's translation presents a very oddfictional scenario that is far-removed from the facts of the SL text:

\begin{tabular}{|l|l|}
\hline Control Version & $\begin{array}{l}\text { And remember in the Book Mary. When she withdrew from her family to an eastern place } \\
\text { and took a veil apart from them. We sent to her Our spirit, and it took for her the form of a } \\
\text { human being exactly. She said, 'Surely I take refuge with the Merciful from you, if you } \\
\text { are one who guards (yourself).' He said, 'I am only a messenger of your Lord (sent) to } \\
\text { grant you a boy (who is) pure. }\end{array}$ \\
\hline Turner-Behbudi & $\begin{array}{l}\text { Recount in your divine Book the story of Mary: she left her family and chose a secluded } \\
\text { spot in the east, where she sat to warm her body in the heat of sun. She was hidden from } \\
\text { her family by a screen of leaves and branches and ears of wheat so that she might disrobe. } \\
\text { Then We sent the Holy Spirit, who appeared before her in human guise. Mary, who was } \\
\text { naked, gasped with fright. "I take refuge from you in God the Compassionate! If you are a }\end{array}$ \\
$\begin{array}{l}\text { God-fearing man, you will fear His punishment and not take advantage of me." Had the } \\
\text { intruder attempted to molest her, Mary planned to run, naked though she was, to her } \\
\text { family for help, but at that point the Holy Spirit spoke: "I am not of the human race: I have } \\
\text { been sent by your Lord to give you a son, pure of heart and spirit." }\end{array}$ \\
\hline
\end{tabular}

Use of explicit lexical items (use of the verb 'disrobe' once and use of the adjective 'naked' twice) is one characteristic features of Turn-Behbudi's version. This reflects the first translator's socio-cultural background, which intrudes into the privacy of women to create sexual scenarios entirely absent from the Qurānic verse. 


\section{Case (9)}

This case shows how different traces of ideology may combine together to produce a fictional scenario that changes a very simple text into a gnostic story with esoteric connotations:

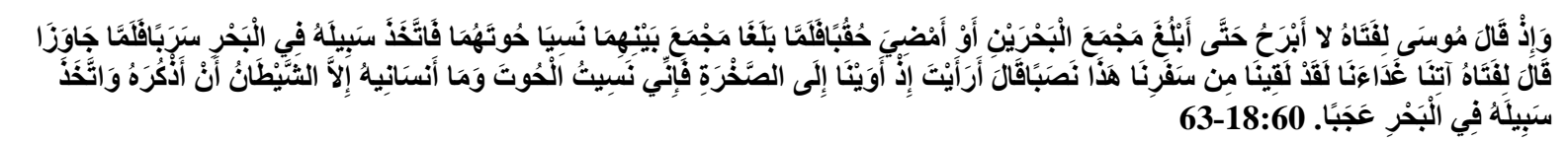

\begin{tabular}{|l|l|}
\hline Control Version & $\begin{array}{l}\text { (Remember) when Moses said to his young man, 'I shall not give up until I reach the } \\
\text { junction of the two seas, or (else) I shall go on for a long time. When they reached the } \\
\text { junction of them, they forget their fish, (for) it had taken its way into sea, swimming off. } \\
\text { So when they had passed beyond (that place), he said to his young man, 'Bring us our } \\
\text { morning meal. We have indeed become weary from this journey of ours.' He said, 'Did } \\
\text { you see when we took refuge at the rock?' Surely I forget the fish- none other than Satan } \\
\text { made me forget to remember it- and it took its way to the sea, swimming off. }\end{array}$ \\
\hline Turner-Behbudi & $\begin{array}{l}\text { And remind them of the day when the servant of Moses said: "O master! Why do you rush } \\
\text { so, moving by day and by night without rest? In this way you may do yourself an injury } \\
\text { and fall behind." Mosses said to his servant: "I shall not stop until I reach the junction of } \\
\text { the two seas, for it is there that I am to meet the green-clad one I have seen in my dreams. }\end{array}$ \\
$\begin{array}{l}\text { I must reach there on time; if I am late I shall have to wait for years before he comes to } \\
\text { drink of the water of life and become rejuvenated, and maybe by that time I shall have left } \\
\text { this world." And when Moses and his servant reached the junction of the two seas, Moses } \\
\text { rested while his servant prepared the fish he had caught for supper. But after waking the } \\
\text { two made haste, forgetting completely about the fish. The servant then put the fish in the } \\
\text { water to wash it, whereupon the fish in the water quickened and stirred, gained new life } \\
\text { and then swam way into the sea. }\end{array}$ \\
\hline
\end{tabular}

One of the paradoxes in interpreting and translating the Qurān is that gnostic agendas often combine with other traces of ideologies to produce peculiar versions. Gnosis is an esoteric philosophy which maintains that a special type of knowledge (Gnosis) is obtained through understanding at which one can arrive via inner personal experience or (kashf). This kind of knowledge builds on religio-philosophical mystical systems rather than knowledge derived from the practices of faith. In the history of Islamic thought, the term esoteric (batin) refers to the inner meaning of a sacred text, and exoteric (zahir) to the apparent meaning. Gnostic interpretations are often abundant in Sufi and Shi'i interpretations of the Qurān as esoteric perspectives often rely on the inner meanings perceived and shaped by the reader's own personal or intuitive experience and motivated by their spiritual capacity and ideological stance.

Turner-Behbudi's version above alludes to a gnostic reading of the Qurān. From the first days of the drastic change of Shi' ism from a political perspective into a distinct school that embodies its own beliefs and dogmas, gnosis has had a decisive role in shaping its course. Allusions to the 'green-clad' and the 'water of life' reflect the esoteric traces of ideology that combine with the authors' sectarian background to create this sort of fictional scenario.

\section{MAJOR FINDINGS AND IMPLICATIONS}

- Traces of ideology are the underlying root of 'fictional scenarios' in translating the Qurān to English. All the cases sampled in this article are ideologically-motivated. This points out to the strong and significant role of ideological and sectarian bias in creating fictional scenarios in translating the Qurān into English as ideological agendas always produce fictional scenarios which the SL text never accommodates.

- Neo-Mutazilte schemata contribute to some types of distortion in translating some personal pronouns in order to negate some miraculous events narrated in the Qurān.

- Paradoxically, the desire to validate the Qurān through accommodating the current scientific theories underpins a significant portion of fictional scenarios in translating the Qurān into English that drastically alter the Qurānic message.

- Sufi perspectives have their own legacy in interpreting particular verses to produce fictional scenarios that endorse particular Sufi and gnostic beliefs.

- In some of the cases explored, fictional scenarios are in direct opposition with each other. The first case in the article clearly illustrates this conclusion. 
- Complex traces of ideology may combine to create odd fictional scenarios in translating the Qurān as clearly seen in case (9).

\section{REFERENCES}

[1] Abdel Haleem, M.A.S. (2004). The Qurān. Oxford University Press

[2] Abu Zayd, N. (2006). Reformation of Islamic thought: a critical historical analysis. Amesterdam University Press

[3] Ahmed, S. (2012). The Qurān as it explains itself. Lighthouse

[4] Aichele, G. (2002). Translation as de-canonization: Matthew's Gospel according to Pasolini. Retrieved February 8, 2013 from: http://home.comcast.net/ gcaichele/writings/pasolinimatthew.pdf

[5] Ali, A. (1984). Al-Qurān: a contemporary translation. Princton University

[6] Ali, M. M. (1973). The holy Qurān: Arabic text, English translation and commentary. Ahmadiyyah Anjuman Isha'at Islam

[7] Al-Shabab, O. S. (2001). The place of Marracci's Latin translation of the holy Quran: a linguistic investigation. Journal of King Saud University, Language and Translation: 13; 57-74

[8] Al-Shabab, O. S. (2008). From necessity to infinity: interpretation in language and translation. Janus Publishing Company

[9] Asad, M. (1980). The message of the Qurān. Gibraltar: Dar Al-Andlus

[10] Baucille, M. (2003). The Bible, the Qurān, and science: the Holy Scriptures examined in the light of modern knowledge. Kazi Publications

[11] Dörnyei, Z. (2007). Research methods in applied linguistics. Oxford University Press

[12] Droge, A. J. (2013). The Qurān: a new annotated translation. Equinox Publishing

[13] Eagleton. T. (2003). Literary theory: an introduction. Blackwell Publishers Ltd.

[14] El Mallah, F. (2008). Arabic-English translational crossover viewed from a linguistic/cultural perspective with special reference to the major principles of translating the Quran. LAP LAMBERT Academic Publishing

[15] Hatim B. and I. Mason (1997). The translator as communicator. London, Routledge

[16] Khan, M. Z. (2007). The Qurān: The word as revealed by Muhammad. Arthur's Classic Novels

[17] Kidwai, A. (1987). Translating the untranslatable: a survey of English translations of the Qurān. Retrieved November 18, 2012 from: https://www.soundvision.com/info/quran/english.asp

[18] Lefevere, A. (2004). Translation, rewriting and the manipulation of literary fame. Routledge

[19] Monotheist Group. (2012). The natural republic: reclaiming Islam from within. Brainbow Press

[20] Musa, A. Y. (2010). The Qurānist. Religion Compass 4/1 (2010): 12-21, 10.1111/j.1749-8171.2009.00189.x

[21] Qurān. Islamawakened. Retrieved February 10, 2015 from: http://islamawakened.com/quran/

[22] Rafiabadi, H. N. (2003). World religions and Islam: a critical study, part I. Sarup and Sons

[23] Robinson, N. (2007). Sectarian and ideological bias in Muslim translations of the Qurān. Islam and Christian-Muslim Relations, 8:3, 261-278. Routledge

[24] Rehman, J. (2003). Searching for scientific facts in the Qurān: Islamization of knowledge or a new form of scientism? Islam \& Science 1.2 (Dec 2003): 245

[25] Ross, A. (1649). The Alcoran of Mahmet by Sier Du Ryer. London

[26] Shah, Z. (2011). Forty different simultaneous translations of the Holy Qurān in English. Retrieved December 18, 2012 from: http://www.themuslimtimes.org/2012/02/religion/islam/forty-different-simultaneous-translations-of-the-holy-Qurānin-english

[27] Sideeg, A.I (2014). Sources of linguistic variations in the translation of the Qurān: a critical discourse analysis of eighty versions of the Qurān in English. Unpolished PhD Thesis at Omdurman Islamic University

[28] Sideeg, A. I. (2015). Traces of Ideology in Translating the Qurān into English: A Critical Discourse Analysis of Six Cases across Twenty Versions.doi:10.7575/aiac.ijalel.v.4n.5p.214 http://www.journals.aiac.org.au/index.php/ IJALEL/article/ view/1585

[29] Starkovsky, N. (2005). The Koran handbook: an annotated translation. Algora Publishing, New York

[30] Tarazi, O. (2012). Allah's Words in Plain English. Independent Publisher

[31] Tavakoli, H. (2013), a dictionary of research methodology and statistics in applied linguistics. Rahnama Press

[32] Turner, C. and M. B. Behbudi. (1997). The Qurān: a new interpretation. Curzon Press

[33] Tymoczko, M. and E. Gentzler (eds.). (2002). Translation and power. Amherst, MA: University of Massachusetts Press

[34] Uqdah, M. (2010). Social resurrection: Abraham and the four birds. http://www.ascertainthetruth.com/att/index.php/alislam/understaningalislam/259-social-resurrection-abraham-and-the-four-birds 
American Research Journal of English and Literature, Volume 1, Issue 3, June 2015

ISSN 2378-9026

[35] Van Dijk T. A. (2006). Ideology and discourse analysis. Journal of Political Ideology, 11(2), 115-140. Routledge [36] Zidan, A. and D. Zidan (1996). The glorious Quran: text and translation. Islamic Inc. Publishing \& Distribution

\section{ARABIC REFERENCE}

ابنتيمية،/حمدبنعبدالحليم (2004). مجمو عالفتاوي: الجزءالساد. مجمعالملكفهلطباعة|المصحفالثريف

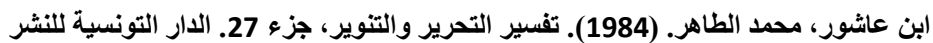

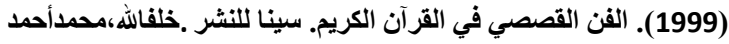

رضا،محمدرشيد. (1947). تفسير القر آنالحكيم : الثهيربـ "تفسير المنار". مطبعة المنار

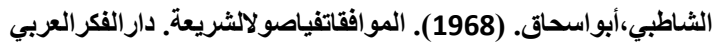

الطبري، أبي جعر محمد بن جرير. (2001). تفسير الطبري جامع البيان عن تأويل آي القرآن، جزء 24. مركز البحوث والدراسات الاسلامية 